ISSN 1330-3651(Print), ISSN 1848-6339 (Online) https://doi.org/10.17559/TV-20160122124303

\title{
OPTIMISATION OF METAL-TO-COMPOSITE BONDED JOINTS WITH VARIOUS ADHESIVE LAYER CONFIGURATIONS USING FINITE ELEMENT METHOD
}

\author{
Václava Lašová, Petr Bernardin, František Sedláček
}

Original scientific paper

The purpose of this paper was to optimise several bonded joints using the optimisation cycle implemented in finite element analysis (FEA) software. These bonded joints were compared to each other based on different geometry and strength obtained by the optimisation cycle. For these bonded joints the bonded surfaces had various shapes and parameters. The impact of the length, thickness and cross-section angle of the adhesive layer on the resulting stress level and the final relative twist angle between a composite tube and a steel flange have been investigated. Specimens with cylindrical bonding surface were used as the reference shape, which influenced the calculated strength of the specimens. The shape of the bonded joint is in accordance with the bonded joints used for transmitting torque to machine tool spindles in machine tool design and results of this research will be used for similar applications.

Keywords: bonded joints; composite material; finite element analysis; metal-to-composite joints; optimisation cycle

\section{Usporedba između veznih spojeva od metala i kompozita povezanih različitim konfiguracijama veznog spoja primjenom metode konačnih elemenata}

Izvorni znanstveni članak Cilj ovoga rada bio je optimizirati nekoliko veznih spojeva primjenom ciklusa optimizacije implementiranog u softveru analize konačnih elemenata. Ti spojevi su međusobno uspoređeni na osnovu različite geometrije i čvrstoče postignute ciklusom optimizacije. Za tako povezane spojeve vezne su se površine uspoređivale na osnovu različite geometrije i čvrtoće postignute ciklusom optimizacije. Kod tih spojeva vezne su površine bile različitih oblika i parametara. Ispitivao se utjecaj dužine, debljine i kuta poprečnog presjeka adhezijskog sloja na rezultirajuću razinu naprezanja i završni relativni kut uvijanja između cijevi od kompozita i prirubnice od čelika. Kao referentni oblik korišteni su uzorci s cilindričnom veznom površinom što je utjecalo na proračunsku čvrstoću uzoraka. Oblik veznog spoja je u skladu s veznim spojevima rabljenim za prenošenje zakretnog momenta vretenima alatnog stroja kod projekta alatnog stroja pa će se rezultati ovoga istraživanja primijeniti za slične aplikacije.

Ključne riječi: analiza konačnih elemenata; ciklus optimizacije; kompozitni materijal; spojevi metala i kompozita; vezni spojevi

\section{Introduction}

The use of composite materials in many industrial sectors has been increasing steeply over the recent years. The machinery industry is no exception [2]. Fabricated structures typically consist of two or more parts. As high demands are placed on the stiffness and strength of the joints between them, the joining techniques are of key importance. Joints tend to be the weakest point in a structure, which is why designers must pay increased attention to them when designing and sizing the fabricated products, with respects to the environmental influences [3]. The presented study deals with an adhesive-bonded joint between composite material and metal. The properties of this joint have been predicted with the aid of FEA-based numerical simulations. Numerical simulations of bonded joints can be carried out by multiple methods. Some methods describe only the linear cohesive behaviour of the joint. Others describe also the area of the damage evolution. One can classify these methods according to the way the adhesive layer is idealised and according to the extent of idealisation of both adherents. The adhesive layer can be represented by $1 \mathrm{D}, 2 \mathrm{D}$ or $3 \mathrm{D}$ elements. Using 1D elements, the adhesive layer can be idealised as spring elements or as a combination of spring elements and infinite-stiffness $1 \mathrm{D}$ elements. This concept of adhesive layer idealisation is employed in the Tahmasebi model [4]. With 3D elements, the adhesive layer can be defined as isotropic material. The problem can then be solved in the elastic strain range using Hooke's law and cohesive surface contact [5], or with the aid of $3 \mathrm{D}$ cohesive elements $[6,7]$. These elements can be related to Griffith's theory of fracture [8]. One can model the two parts to be bonded by means of $3 \mathrm{D}$ or $2 \mathrm{D}$ elements. The purpose of this study was to find the optimum configuration of the adhesive layer to facilitate the transmission of torque between composite material and metal. The findings will be used for developing an experimental specimen on which the properties of the joint and the results of the numerical model will be verified.

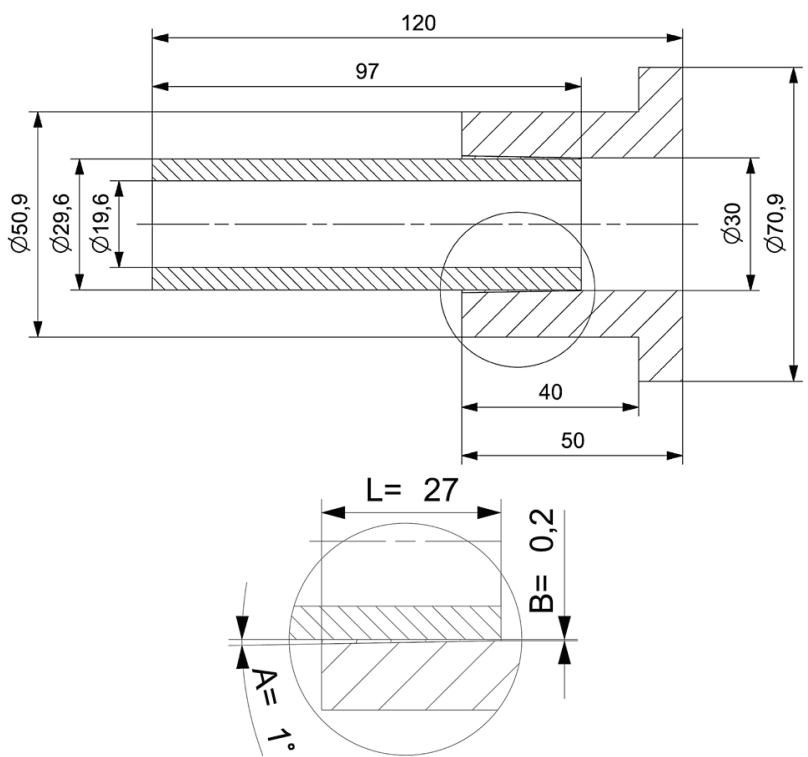

Figure1 Shape of specimen and the detail view 


\section{Shape of the specimen}

Fig. 1 shows a bonded joint between a composite tube and a steel flange. It also contains the dimensions of both adherends (lengths, thicknesses and diameters).

Fig. 1 also shows a detail of the adhesive layer with dimensions (length, thickness and the cross-section angle of the adhesive layer). These parameters are the input data for the optimisation cycle [1]. The objective function relates to the twist angle at the end of the composite tube. The purpose of the optimisation is to minimise this twist angle. The properties of the adhesive are given in Tab. 1.

Table 1 Material parameters of the adhesive Spabond 345 LV [8]

\begin{tabular}{|l|c|c|}
\hline \multicolumn{1}{|c|}{ Parameter } & Value & Unit \\
\hline Mass density & 1300 & $\mathrm{~kg} / \mathrm{m}^{3}$ \\
\hline Young's modulus & 3000 & $\mathrm{MPa}$ \\
\hline Poisson's ratio & 0,37 & - \\
\hline Yield strength & 27 & $\mathrm{MPa}$ \\
\hline Type of material & Isotropic & - \\
\hline
\end{tabular}

Table 2 Material properties of composite layer

\begin{tabular}{|c|c|c|}
\hline \multicolumn{2}{|c|}{ Matrix } & $V_{\mathrm{m}}$ \\
\hline \multicolumn{2}{|c|}{ Epoxy resin } & 0,3 \\
\hline \multicolumn{2}{|c|}{ Fibre } & $V_{\mathrm{f}}$ \\
\hline \multicolumn{2}{|c|}{$\mathrm{T} 700$} & $E_{3} / \mathrm{MPa}$ \\
\hline$E_{1} / \mathrm{MPa}$ & $E_{2} / \mathrm{MPa}$ & 6627 \\
\hline 167662 & 6627 & $v_{31} /-$ \\
\hline$v_{12} /-$ & $v_{23} /-$ & 0,013 \\
\hline 0,329 & 0,326 & $G_{31} / \mathrm{MPa}$ \\
\hline$G_{12} / \mathrm{MPa}$ & $G_{23} / \mathrm{MPa}$ & 5116 \\
\hline 5116 & 2498 & \\
\hline
\end{tabular}

Table 3 Description of layers of the composite tube

\begin{tabular}{|c|c|c|}
\hline Layer number & Thickness / mm & Fibre orientation $/{ }^{\circ}$ \\
\hline 1 & 0,25 & 45 \\
\hline 2 & 0,25 & -45 \\
\hline 3 & 0,25 & 45 \\
\hline 4 & 0,25 & -45 \\
\hline 5 & 0,25 & 45 \\
\hline 6 & 0,25 & -45 \\
\hline 7 & 0,25 & 45 \\
\hline 8 & 0,25 & -45 \\
\hline 9 & 0,25 & 45 \\
\hline 10 & 0,25 & -45 \\
\hline 11 & 0,25 & 45 \\
\hline 12 & 0,25 & -45 \\
\hline 13 & 0,25 & 45 \\
\hline 14 & 0,25 & -45 \\
\hline 15 & 0,25 & 45 \\
\hline 16 & 0,25 & -45 \\
\hline 17 & 0,25 & 45 \\
\hline 18 & 0,25 & -45 \\
\hline 19 & 0,25 & 45 \\
\hline 20 & 0,25 & -45 \\
\hline
\end{tabular}

Tab. 1 also contains values which describe the behaviour of the adhesive in the elastic region. These are Young's modulus and Poisson's ratio. Yield strength represents the limit value beyond which plastic deformation occurs. Material properties of individual laminae of the composite tube are listed in Tab. 2, where Young's modulus, Poisson's ratio and Shear modulus are given for the fibre direction and both directions perpendicular to the fibres.
The matrix and fibre volume fractions in the lamina and the type of fibres and the adhesive are listed as well. These values have been derived from the volume fractions and material parameters of the fibres and the adhesive.

The stiffness and strength of the bonded joint are dictated primarily by the stiffness and strength of the composite tube which is governed predominantly by the composite's structure. The description of the layers, the fibre orientation and layer thickness are given in Tab. 3 . The orientation of fibres in individual layers has been proposed with regard to the acting load.

\section{Finite element analysis}

Numerical simulations were carried out using finite element method implemented in the Siemens NX 10.0 software with the NX NASTRAN 10 solver. The model of the steel flange to which the composite tube is attached was meshed using 3D CTETRA (10) elements with a size of $12 \mathrm{~mm}$. The flange is made of steel, the properties of which are given in Tab. 4.

Table 4 Material parameters of steel

\begin{tabular}{|l|c|c|}
\hline \multicolumn{1}{|c|}{ Parameter } & Value & Unit \\
\hline Mass Density & 7829 & $\mathrm{~kg} / \mathrm{m}^{3}$ \\
\hline Young's modulus & 210000 & $\mathrm{MPa}$ \\
\hline Poisson's ratio & 0,31 & - \\
\hline Type of material & Isotropic & - \\
\hline
\end{tabular}

Identical elements have been used for the adhesive layer. However, the element size $(1 \mathrm{~mm})$ was adapted to the adhesive layer thickness. In the composite tube, 2D CQUAD (8) elements with a size of $3 \mathrm{~mm}$ were used. A load of $300 \mathrm{~N} \cdot \mathrm{m}$ was imposed on the bonded joint. The axis of rotation was the axis of the composite tube. The torque was defined with respect to the centre of the composite tube using infinite-stiffness RBE2 elements. The bond between the adhesive layer and the composite tube was defined by means of Surface-to-Surface Gluing. The attachment constraint was defined on the front face of the flange, see Fig. 2.

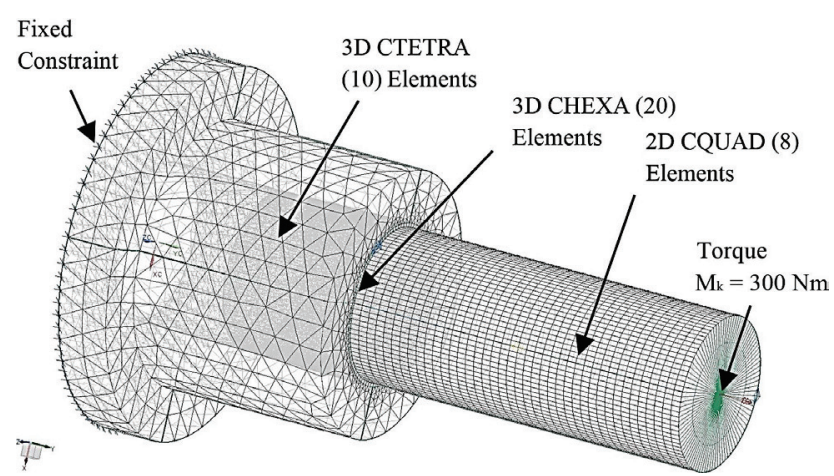

Figure 2 Application of boundary conditions and meshing of the model of the bonded joint

The stress and the twist angle determined by the finite element analysis are input into the optimisation cycle.

\section{Optimisation of the bonded joint}

The purpose of the optimisation cycle was to find an optimum configuration of the adhesive layer. Such a 
configuration should minimise the twist in the bonded joint caused by the torque, taking into account the stress in the layer. The numerical simulation was a basis for the subsequent optimisation. The optimisation was done using the special Geometry Optimization cycle incorporated in the Siemens NX 10 environment. The optimisation variables included the length $L$, the adhesive layer thickness $B$ and its cross-section angle $A$, as recorded in step 1 of the optimisation cycle documented in Tab. 5.

Table 5 Description of the optimised parameters of the layer of adhesive \begin{tabular}{|l|l|l|l|l|l|}
\hline Optimisation & Rotation & Angle & Length & Thickness & Shear stress \\
\hline
\end{tabular}

\begin{tabular}{|c|c|c|c|c|c|}
$\begin{array}{c}\text { Optimisation } \\
\text { Cycle No. }\end{array}$ & $\begin{array}{c}\text { Rotation } \\
{ }^{\circ}\end{array}$ & $\begin{array}{c}\text { Angle } \\
A /{ }^{\circ}\end{array}$ & $\begin{array}{c}\text { Length } \\
L / \mathrm{mm}\end{array}$ & $\begin{array}{c}\text { Thickness } \\
\mathrm{B} / \mathrm{mm}\end{array}$ & $\begin{array}{c}\text { Shear stress } \\
/ \mathrm{MPa}\end{array}$ \\
\hline 1 & 0,362 & 4,00 & 15,00 & 0,75 & 28,28 \\
\hline 2 & 0,361 & 3,10 & 15,00 & 0,75 & $\mathbf{3 4 , 2 4}$ \\
\hline 3 & 0,351 & 4,00 & 17,00 & 0,75 & $\mathbf{2 9 , 9 1}$ \\
\hline 4 & 0,347 & 4,00 & 15,00 & 0,59 & $\mathbf{3 7 , 6 1}$ \\
\hline 5 & 0,326 & 5,00 & 24,87 & 0,75 & 22,78 \\
\hline 6 & 0,326 & 4,57 & 24,92 & 0,75 & 24,22 \\
\hline 7 & 0,288 & 4,59 & 29,72 & 0,48 & 21,78 \\
\hline 8 & 0,247 & 0,87 & 29,60 & 0,20 & 21,80 \\
\hline 9 & 0,271 & 5,00 & 28,47 & 0,20 & 23,48 \\
\hline 10 & 0,307 & 0,50 & 30,00 & 1,00 & 21,71 \\
\hline 11 & 0,248 & 0,50 & 30,00 & 0,28 & 22,05 \\
\hline 12 & 0,243 & 0,50 & 30,00 & 0,20 & 22,91 \\
\hline 13 & 0,242 & 0,50 & 30,00 & 0,20 & 22,37 \\
\hline
\end{tabular}

The objective function involves the resulting twist angle of the bonded joint measured at the end of the tube where the torque of $300 \mathrm{~N} \cdot \mathrm{m}$ is applied. The objective is to minimise the twist angle. Another parameter of interest is the resulting shear stress in the adhesive layer which should not exceed the permitted value of $(29 \div 35 \mathrm{MPa}$ [8], depending on ambient conditions). It was necessary to define the upper and lower limits of input parameters for the optimisation cycle, see Tab. 6 .

Table 6 Initial input parameters for the optimisation cycle

\begin{tabular}{|c|l|c|c|c|c|}
\hline Symbol & $\begin{array}{c}\text { Description of } \\
\text { parameter }\end{array}$ & $\begin{array}{c}\text { Initial } \\
\text { value }\end{array}$ & $\begin{array}{c}\text { Upper } \\
\text { limit }\end{array}$ & $\begin{array}{c}\text { Lower } \\
\text { limit }\end{array}$ & Unit \\
\hline$L$ & $\begin{array}{l}\text { Length of the } \\
\text { bonded joint }\end{array}$ & 27 & 20 & 30 & $\mathrm{~mm}$ \\
\hline$B$ & $\begin{array}{l}\text { Minimal thickness } \\
\text { of the bonded joint }\end{array}$ & 0,75 & 1 & 0,2 & $\mathrm{~mm}$ \\
\hline$A$ & $\begin{array}{l}\text { Angle of the } \\
\text { section area of the } \\
\text { bonded joint }\end{array}$ & 4 & 5 & 0,5 & $\circ$ \\
\hline
\end{tabular}

Effects of individual input parameters and their changes with optimisation cycle steps are plotted in Fig. 3 $\div$ Fig. 6 . These parameters include the bonded joint twist angle, the adhesive layer cross-section angle $(A)$, the length of the adhesive layer $(L)$ and the adhesive layer thickness $(B)$. The lowest value of the final twist angle of the bonded joint was found in step 12. In this step, the monitored stress level was just below the permitted value. The stress levels are shown in Tab. 5. The stresses, which exceed the permitted value [8], are highlighted in bold italics.

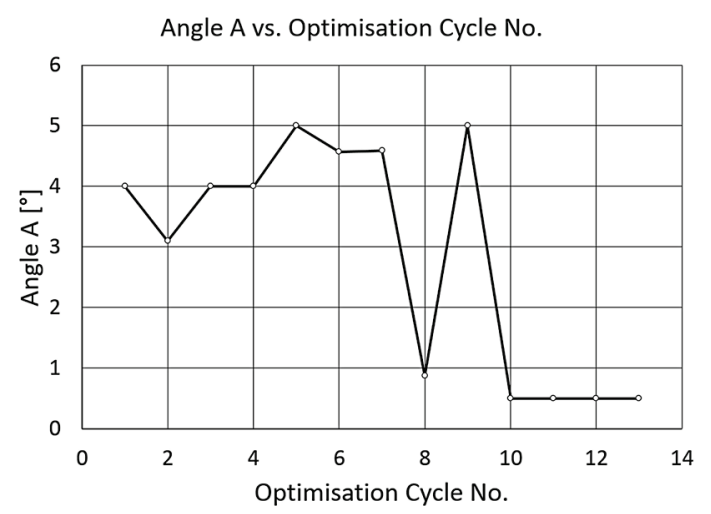

Figure 3 The relationship between the angle and the number of the optimization cycle

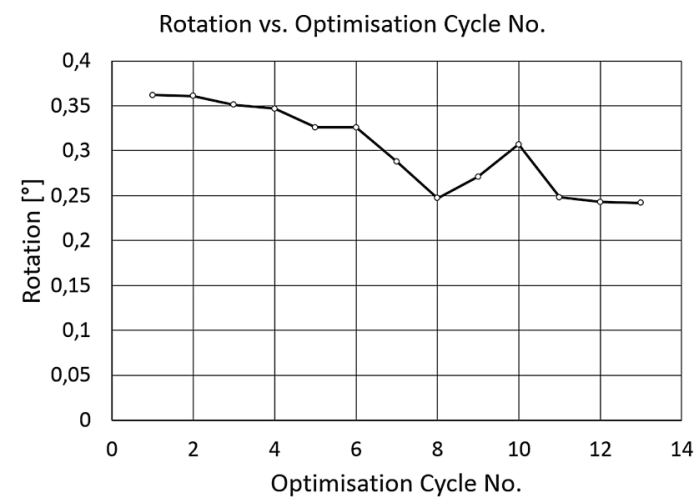

Figure 4 The relationship between the rotation and the number of the optimization cycle

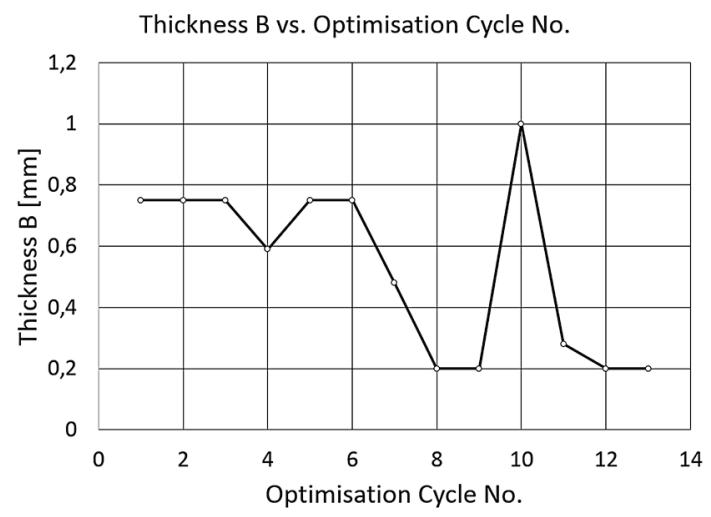

Figure 5 The relationship between the thickness and the number of the optimization cycle

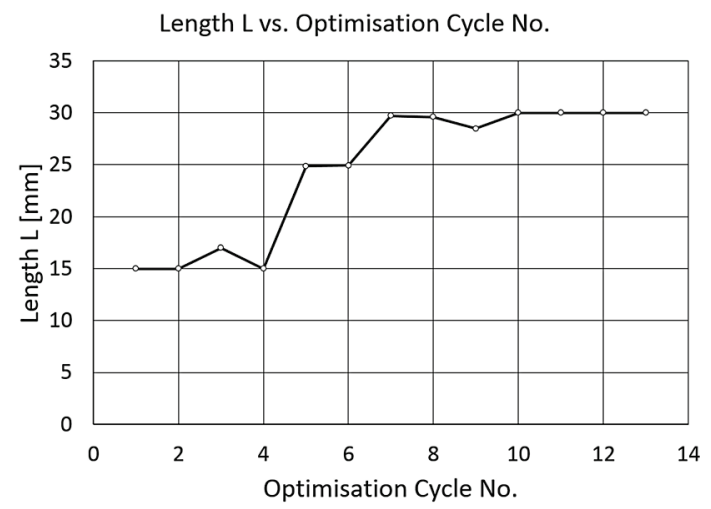

Figure 6 The relationship between the length and the number of the optimization cycle 


\section{Conclusion}

In this study, a set of optimisation cycles has been carried out to find the appropriate input parameters. These input parameters should minimise the twist angle in the bonded joint. In addition, the shear stress value should not exceed the limit value specified by the adhesive producer [8]. In the last optimisation step, optimum parameters were found which minimise the twist angle in the bonded joint. This optimum value is $0,242^{\circ}$ and is valid for used type of the bonded joint with specific geometry and for used numerical model. The optimum input parameter values are as follows: bonded joint length $L=30 \mathrm{~mm}$, cross-section angle of the adhesive layer $A=0,5^{\circ}$, adhesive layer thickness $T=0,2 \mathrm{~mm}$. The stress in the layer of adhesive under the above conditions is $22,37 \mathrm{MPa}$. This value is much lower than the limit value. In the optimisation cycle, the input parameter values of $\mathrm{A}$, $\mathrm{L}$ and $\mathrm{T}$ were affected most strongly by the upper and lower limits defined for the cycle. These limits were derived from the process requirements for joint making and from the design requirements for the bonded joint of this type. The lower limit for the adhesive layer thickness was influenced by the minimum thickness defined by the adhesive manufacturer. The same holds for the minimum angle of this layer which should guarantee uniform distribution of the adhesive during the joint-making process. The length of the bonded joint was also influenced by the dimensional constraints of the bonded joint design. The optimisation cycle shows a similar sensitivity to changes in the cross-section angle of the adhesive layer $(A)$ and the change in the adhesive layer thickness $(T)$ all the way down to their lower limits; and to changes in the bonded joint length $(L)$ all the way up to its upper limit. The effect of changes in the input parameters on the total mass of the joint was neglected, as it was very small. The $A, L$ and $T$ parameters describe the optimum configuration of the adhesive layer. They will be used for designing the structure which transmits the torque to machine tool spindles and that is the main contribution of this research.

\section{Acknowledgements}

This paper is based upon the work sponsored under the project "Comprehensive support for designing of technical equipment" no. SGS-2016-012.

\section{References}

[1] Janda, P.; Kosnar, M.; Kroupa, T.; Lašová, V.; Vacík, J. Využití programů ANSYS a OPTISLANG v konstrukci výrobních strojů. // Proceedings of the ANSYS conference / Frymburk, 2010, pp. 1-8.

[2] Thori P.; Sharma P.; Bhargava M. An Approach of Composite Material in Industrial Machinery: Advantages, Disadvantages and Applications. // IJRET: International Journal of Research in Engineering and Technology, eISSN:2319-1163 (2013), pp. 350-355.

[3] Müller, M.; Herák, D.; Valášek, P. Degradation limits of bonding technology depending on destinations Europe and Indonesia. // Tehnički vjesnik. 20, 4(2013), pp. 571-575
[4] Tahmasebi, F. P. Finite Element Modeling of an Adhesive in a Bonded Joint, NASA Goggard Space Flight Center, 1999.

[5] Bernardin, P.; Vacík, J.; Kroupa, T.; Kottner, R. Determination of the mechanical parameters of a bonded joint between a metal and a composite by comparing experiments with a finite-element model. // Materiali in tehnologije. 47, 4(2013), pp. 417-421.

[6] Benzeggagh, M. L.; Kenane, M. Measurement of MixedMode Delamination Fracture Toughness of Unidirectional Glass/EpoxyComposites with Mixed-Mode Bending Apparatus. // Composites Scienceand Technology. 56, 4(1996), pp. 439-449. https://doi.org/10.1016/0266-3538(96)00005-X

[7] Camanho, P. P.; Davila, C. G. Mixed-Mode Decohesion Finite Elements for the Simulation of Delamination in Composite Materials, NASA/TM-2002-211737, NASA LangleyResearchCenter, Virginia, USA, 2002.

[8] Griffith, A. A. The Phenomena of Rupture and Flow in Solids. // Philosophical Transactions, Series A. 221(1920), pp. 163-198. https://doi.org/10.1098/rsta.1921.0006

[9] Spabond, Epoxy Adhesive System. Gurit Ltd. 2004. http://www.gurit.com/files/documents/ (12.06.2012).

\section{Authors' addresses}

Václava Lašová, doc. Ing. Ph.D.

University of West Bohemia in Pilsen,

Department of Machine Design

Univerzitní 22, 30614 Plzeň, Czech Republic

E-mail: lasova@kks.zcu.cz

Petr Bernardin, Ing.

University of West Bohemia in Pilsen,

Department of Machine Design

Univerzitní 22, 30614 Plzeň, Czech Republic

E-mail: berny@kks.zcu.cz

František Sedláček, Ing.

University of West Bohemia in Pilsen,

Department of Machine Design

Univerzitní 22, 30614 Plzeň, Czech Republic

E-mail: fsedlace@kks.zcu.cz 